\title{
FAKTOR-FAKTOR YANG MEMPENGARUHI HASIL BELAJAR AKUNTANSI KEUANGAN MENENGAH
}

\author{
Andri Eko Prabowo \\ Universitas Islam Riau \\ andre.e.prabowo@gmail.com
}

\begin{abstract}
This research is designed to analyze the indirect influences of learning orientation, interaction among students, intensity of accessing social media and technical ability toward learning outcome of intermediate financial accounting through learning motivation as mediating variable on students of FKIP Universitas Islam Riau. In analyzing the mediator variable (learning motivation), Sobel Test is applied. Meanwhile, direct influence toward learning motivation and learning outcome is analyzed using SEM. The findings in this research are showing that 1) learning orientation, interaction among students, intensity of accessing social media and technical ability influence directly to the learning motivation; 2) there is no direct influences of learning orientation, interaction among students, intensity of accessing social media and technical ability to the learning outcome; 3) learning motivation influence directly to the learning outcomer; 4) learning orientation, interaction among students, intensity of accessing social media and technical ability influence indirectly to the learning outcome through the learning motivation.
\end{abstract}

Key words: learning orientation, interaction among students, the intensity of accessing social media, technical ability, learning motivation, learning outcome.

\begin{abstract}
Abstrak : Penelitian ini bertujuan untuk mengetahui pengaruh tidak langsung orientasi belajar, interaksi antar mahasiswa, intensitas akses media sosial, dan kemampuan teknis terhadap hasil belajar akuntansi keuangan menengah melalui motivasi belajar pada mahasiswa FKIP Universitas Islam Riau. Dalam pengujian variabel mediator (motivasi belajar) digunakan analisis jalur yang diuji dengan uji sobel (Sobel Test), sedangkan dalam pengujian pengaruh langsung terhadap motivasi dan hasil belajar digunakan model analisis SEM. Hasil penelitin ini menunjukkan bahwa 1) orientasi belajar, interaksi antar mahasiswa, intensitas akses media sosial dan kemampuan teknis berpengaruh secara langsung terhadap motivasi belajar; 2) tidak ada pengaruh langsung orientasi belajar, interaksi antar mahasiswa, intensitas akses media sosial, kemampuan teknis terhadap hasil belajar; 3) motivasi belajar berpengaruh langsung terhadap hasil belajar; 4) orientasi belajar, interaksi antar mahasiswa, intensitas akses media sosial dan kemampuan teknis, berpengaruh tidak langsung terhadap hasil belajar melalui motivasi belajar.
\end{abstract}

Kata kunci : orientasi belajar, interaksi antar mahasiswa, intensitas akses media sosial, kemampuan teknis, motivasi belajar, hasil belajar

Evaluasi pendidikan merupakan suatu proses penghimpunan informasi yang terkait dengan pelaksanaan dan hasil yang dicapai oleh lembaga pendidikan. Porsi terbesar dari evaluasi pendidikan adalah pada aspek akademik, yang lebih difokuskan pada kinerja 
proses dan hasil belajar yang dijadikan indikator keberhasilan proses belajar mengajar (Ibrahim dan Ali, 2007: 104). Hasil belajar yang evaluasinya dapat dilakukan secara kuantitatif-objektif dengan prosedur yang dapat distandarisasikan adalah hasil belajar dalam bidang kognitif dengan menggunakan tes yang telah distandarisasikan (Dyer dalam Ibrahim dan Ali, 2007:107).

Sebagai indikator utama keberhasilan pembelajaran, hasil belajar memperoleh porsi perhatian yang besar dari berbagai stakeholder pendidikan. Oleh karena itu berbagai upaya untuk meningkatkan hasil belajar telah banyak dilakukan, baik dalam tingkatan institusi pendidikan maupun oleh pendidik itu sendiri. Salah satu cara yang dipakai oleh Universitas Islam Riau dalam upaya meningkatkan mutu mahasiswanya adalah dengan menerapkan konsep pembelajaran berbasis Teknologi Informasi dan Komunikasi (TIK). Pemilihan konsep pembelajaran ini, lebih disebabkan oleh meningkatnya jumlah mahasiswa yang cukup signifikan tanpa mampu diimbangi oleh sarana prasarana pendidikan yang mendukungnya yang mengakibatkan terkendalanya proses pembelajaran yang berkualitas.

Upaya yang dilakukan universitas untuk meningkatkan mutu lulusan ini, ternyata tidak mampu memberikan hasil sesuai dengan yang diharapkan. Hal ini dapat dilihat dari kecenderungan menurunnya hasil belajar peserta didik dan berbagai keluhan yang disampaikan peserta didik setelah mengikuti kegiatan pembelajaran berbasiskan TIK. Sementara itu, pembelajaran berbasis TIK merupakan salah satu upaya yang harus dilakukan untuk mencapai visi universitas pada tahun 2020, sebagai universitas yang unggul dan terkemuka di kawasan asia tenggara. Oleh karena itu, identifikasi penyebab menurunnya hasil belajar dan solusi atas permasalahan tersebut harus segera ditemukan.

Secara garis besar faktor-faktor yang mempengaruhi hasil belajar terbagi menjadi faktor intrinsik yang berasal dari dalam diri individu dan faktor ekstrinsik yang berasal dari luar diri individu. Faktor intrinsik yang memiliki pengaruh paling besar terhadap hasil belajar adalah motivasi belajar dan orientasi belajar (Knowless, 1970). Selain faktor intrinsik, terdapat faktor ekstrinsik yang turut mempengaruhi hasil belajar pada pendidikan tinggi, yaitu interaksi antar mahasiswa (Woolfolk, 2007), intensitas akses media sosial (Bandura, 1977), dan kemampuan teknis (Noe, 1994). Dengan demikian salah satu cara yang dapat digunakan untuk memperbaiki hasil belajar adalah dengan memperbaiki faktor-faktor yang mempengaruhinya. 


\section{METODE}

Secara umum penelitian ini bertujuan untuk mendeskripsikan dan menganalisis hubungan antar enam variabel (hasil belajar, motivasi belajar, orientasi belajar, interaksi antar mahasiswa, intensitas akses media sosial, dan kemampuan teknis). Penelitian ini termasuk jenis penelitian konfirmatori (confirmatory research). Penelitian dilakukan pada mahasiswa mata kuliah Akuntansi Keuangan Menengah FKIP Universitas Islam Riau, dengan 114 sampel penelitian. Untuk kepentingan pengumpulan data, digunakan kuisioner, wawancara dan dokumentasi. Kuisioner dan wawancara digunakan untuk memperoleh data tentang orientasi belajar, interaksi antar mahasiswa, intensitas akses media sosial, kemampuan teknis dan motivasi belajar responden. Sedangkan teknik dokumentasi digunakan untuk memperoleh data mengenai hasil belajar. Metode analisis untuk melakukan pengujian dengan variabel mediator (motivasi belajar) menggunakan analisis jalur yang diuji dengan uji sobel (Sobel Test). Kemudian untuk menguji pengaruh langsung terhadap motivasi dan hasil belajar menggunakan model analisis SEM.

\section{HASIL}

Berdasarkan hasil analisis struktural menggunakan SEM diketahui bahwa masing-masing variabel bebas (orientasi belajar, interaksi antar mahasiswa, intensitas akses media sosial, kemampuan teknis) berpengaruh secara langsung terhadap motivasi belajar, dengan $t$-value $\geq 1,96$ pada $p$-value 0,05 . Hal ini menunjukkan bahwa hipotesis penelitian diterima pada tingkat signifikansi 5\% yang berarti bahwa masing-masing variabel bebas berpengaruh langsung terhadap motivasi belajar. Kemudian dengan menggunakan metode analisis SEM untuk menguji pengaruh masing-masing variabel bebas terhadap hasil belajar, diperoleh nilai $t$-value $<1,96$ pada $p$-value 0,05 . Hal ini mengindikasikan bahwa Ho ditolak, yang artinya tidak ada pengaruh langsung masing-masing variabel bebas terhadap hasil belajar. Sedangkan pengaruh langsung motivasi belajar terhadap hasil belajar dengan menggunakan metode analisis yang sama diperoleh loading factor sebesar 0,71 dengan $t$-value 7,6 pada $p$-value 0,05 . Hal ini menunjukkan bahwa hipotesis penelitian diterima, yang berarti bahwa pengaruh langsung motivasi belajar terhadap hasil belajar sebesar $71 \%$ pada taraf signifikansi $5 \%$. 
Pengujian hasil analisis data dengan menggunakan analisis jalur melalui uji sobel (sobel test) diketahui bahwa secara berturut-turut koefisien pengaruh tidak langsung orientasi belajar, interaksi antar mahasiswa, intensitas akses media sosial dan kemampuan teknis, melalui motivasi belajar terhadap hasil belajar sebesar 0,25; 0,1435; 0,1079; dan 0,0861, dengan p-value < 0,05. Hal ini menunjukkan bahwa hipotesis penelitian diterima pada taraf signifikansi 5\%, yang berarti orientasi belajar, interaksi antar mahasiswa, intensitas akses media sosial dan kemampuan teknis, berpengaruh tidak langsung terhadap hasil belajar melalui motivasi belajar .

\section{PEMBAHASAN}

Berdasarkan hasil analisis data, diketahui bahwa orientasi belajar tidak berpengaruh positif dan signifikan terhadap hasil belajar akuntansi keuangan menengah. Hal ini berarti perubahan yang terjadi pada orientasi belajar tidak akan langsung berpengaruh terhadap hasil belajar yang dicapai mahasiswa. Hasil penelitian ini tidak sesuai dengan teori andragogi yang dikemukakan oleh Knowles (1970) yang menyatakan bahwa orientasi belajar berpengaruh kuat terhadap hasil belajar. Selain itu, hasil penelitian ini juga tidak konsisten dengan penelitian sebelumnya yang menyatakan bahwa orientasi belajar berhubungan kuat dengan hasil belajar. Orientasi belajar sebagai suatu hal yang mendasari seseorang berperilaku, menurut intentional learning theory terbagi menjadi aspek afektif, kognitif dan sosial. Tidak adanya pengaruh positif dan signifikan pada penelitian ini disebabkan oleh orientasi belajar mahasiswa FKIP-UIR yang cenderung ke arah non kependidikan, yaitu lebih didasarkan pada adat istiadat setempat. Adat istiadat yang dimaksud berupa prestise atau kedudukan di masyarakat. Kuliah lebih di prioritaskan untuk meningkatkan kedudukan di mata masyarakat, sehingga orientasi belajar mahasiswa menjadi lebih ke arah untuk meningkatkan daya jual dirinya di masyarakat.

Hasil penelitian ini juga menunjukkan bahwa interaksi antar mahasiswa tidak berpengaruh positif signifikan terhadap hasil belajar. Hal ini berarti perubahan yang terjadi pada interaksi antar mahasiswa FKIP UIR tidak akan langsung berpengaruh terhadap hasil belajar yang dicapainya. Hasil penelitian ini tidak sesuai dengan teori yang dikemukakan oleh Woolfolk (2007) dan tidak konsisten dengan penelitian yang menyatakan bahwa hasil belajar dipengaruhi oleh interaksi antar peserta didik. Hal ini disebabkan oleh interaksi yang terjadi antar mahasiswa sebagian besar lebih ke arah 
aktivitas yang tidak terkait langsung dengan kegiatan pembelajaran. Interaksi yang terjadi lebih ke arah hobi dan bisnis (perdagangan), sementara interaksi yang terkait dengan pembelajaran hanya terjadi selama berlangsungnya kegiatan pembelajaran. Hal inilah yang mengakibatkan interaksi antar mahasiswa yang merupakan salah satu aspek yang paling berpengaruh dalam pendidikan tinggi menjadi tidak produktif, sehingga tidak dapat memberikan pengaruh terhadap hasil belajar yang diperolehnya.

Penelitian ini juga tidak berhasil membuktikan social learning theory (Bandura, 1977) dengan menunjukkan hasil bahwa intensitas akses media sosial tidak memiliki pengaruh positif signifikan terhadap hasil belajar. Hasil ini melemahkan temuan penelitian sebelumnya yang dilakukan oleh Bugman (2012) yang menemukan bahwa blog dan media sosial berpengaruh terhadap hasil belajar siswa. Tidak adanya pengaruh intensitas akses media sosial terhadap hasil belajar mahasiswa FKIP-UIR disebabkan oleh aktivitas mahasiswa itu sendiri. Media sosial lebih banyak digunakan mahasiswa untuk mengakses situs jejaring sosial seperti facebook dan microbloging seperti twitter daripada mengakses website yang lebih informatif seperti blog dan forum internet. Selain itu, pemanfaatan media sosial oleh mahasiswa lebih diprioritaskan untuk keperluan bisnis (perdagangan) daripada untuk keperluan pendidikan. Hal ini merupakan salah satu faktor yang menyebabkan intensitas akses media sosial tidak berpengaruh positif signifikan terhadap hasil belajar.

Hasil analisis juga menunjukkan bahwa kemampuan teknis tidak berpengaruh positif signifikan terhadap hasil belajar. Hal ini berarti perubahan yang terjadi pada kemampuan teknis tidak berpengaruh terhadap hasil belajar yang dicapai mahasiswa. Hasil ini tidak sesuai dengan teori yang dikemukakan oleh Noe (1994), dan tidak konsisten dengan penelitian sebelumnya yang dilakukan oleh Arabasz, e.l. (2003) yang menyimpulkan kemampuan teknis berpengaruh terhadap hasil belajar. Hal ini disebabkan oleh kecenderungan mahasiswa yang malas dalam memanfaatkan keahliannya dalam kegiatan pembelajaran. Mahasiswa lebih memilih memanfaatkan kemampuannya tersebut untuk keperluan bisnis dan pekerjaan yang digelutinya.

Hasil penelitian berhasil membuktikan bahwa motivasi belajar berpengaruh positif dan signifikan terhadap hasil belajar. Artinya, perubahan motivasi belajar akan berpengaruh terhadap hasil belajar mahasiswa. Hasil ini membuktikan kebenaran teori kebutuhan Maslow dan memperkuat penelitian Lim, e.l. (2009) yang menyimpulkan 
bahwa motivasi belajar berpengaruh positif terhadap hasil belajar. Berdasarkan analisis faktor atas dimensi-dimensi pembentuk motivasi belajar diketahui bahwa motivasi intrinsik, motivasi karir, kualitas diri, kemampuan diri, dan motivasi nilai, memiliki besaran yang hampir sama. Namun kemampuan diri memiliki proporsi yang paling tinggi. Hal ini berarti bahwa kemampuan diri merupakan faktor dominan pembentuk motivasi belajar yang mempengaruhi hasil belajar

Berdasarkan hasil analisis data, penelitian ini berhasil membuktikan adanya pengaruh tidak langsung yang positif signifikan orientasi belajar, interaksi antar mahasiswa, intensitas akses media sosial, dan kemampuan teknis terhadap hasil belajar melalui motivasi belajar. Hal ini berarti setiap perubahan yang terjadi pada orientasi belajar, interaksi antar mahasiswa, intensitas akses media sosial, dan kemampuan teknis, secara tidak langsung direspon oleh hasil belajar, melalui motivasi belajar mahasiswa tersebut. Hasil ini konsisten dengan teori dan hasil penelitian yang telah dijelaskan pada subbab-subbab sebelumnya. Pengaruh positif ini terjadi karena mahasiswa FKIP-UIR pada umumnya telah memiliki motivasi belajar yang tinggi dengan orientasi belajar dan kemampuan teknis yang baik, serta telah mempunyai interaksi antar mahasiswa dan intensitas akses media sosial yang cukup tinggi yang mempengaruhi motivasi belajar.

\section{Simpulan dan Saran}

Berdasarkan pembahasan hasil penelitian, motivasi belajar memiliki peranan yang lebih besar dari pada sekedar moderator, melainkan berperan sebagai mediator terhadap hasil belajar. Orientasi belajar, interaksi antar mahasiswa, intensitas akses media sosial, kemampuan teknis, tidak memiliki pengaruh secara langsung terhadap hasil belajar. Namun demikian secara tidak langsung orientasi belajar, interaksi antar mahasiswa, intensitas akses media sosial, kemampuan teknis, memiliki pengaruh positif dan signifikan terhadap hasil belajar melalui motivasi belajar.

Berdasarkan hasil penelitian dapat diketahui bahwa motivasi memiliki peranan yang jauh lebih besar dalam menentukan hasil belajar mahasiswa. Oleh karena itu untuk meningkatkan hasil belajar pada kegiatan pembelajaran berbasis teknologi inforasi dan komunikasi, motivasi peserta didik harus ditingkatkan terlebih dahulu. Cara yang dapat ditempuh untuk meningkatkan motivasi belajar tersebut di antaranya adalah dengan 
mengadakan berbagai seminar tentang konsep diri dan melakukan mentoring guna meningkatkan motivasi belajar peserta didik. Selain itu, universitas juga dapat memberikan berbagai workshop kepada mahasiswa yang terkait dengan pemanfaatan ilmu pengetahuan dari lingkungan kampus ke dalam dunia kerja.

Secara praktis, dalam rangka meningkatkan hasil belajar mahasiswa pada perguruan tinggi yang menerapkan strategi pembelajaran berbasis Teknologi Informasi dan Komunikasi (TIK), perlu mempertimbangkan berbagai faktor yang mempengaruhi hasil belajar terutama motivasi dan orientasi belajar dalam membuat kebijakan yang mendukung implementasi strategi pembelajaran berbasis TIK di lingkungan kampus. Kemudian pendidik juga perlu lebih memperhatikan kesiapan peserta didik, pada saat merancang strategi-strategi pembelajaran berbasis TIK di dalam kegiatan perkuliahan, agar peserta didik tidak mengalami kendala yang berarti di dalam mengikuti kegiatan pembelajaran. Penelitian selanjutnya yang terkait dengan penerapan strategi pembelajaran berbasis TIK di lingkungan pendidikan tinggi yang masih belum banyak di kaji. Sebaiknya dalam rangka mengembangkan ilmu pengetahuan, perlu melibatkan variabel lain dalam penelitiannya, misalnya budaya atau adat-istiadat setempat yang belum di kaji dalam penelitian ini.

\section{DAFTAR RUJUKAN}

Arabasz, Paul; Judith A. Pirani; Dave Fawcett. 2003. Supporting E-Learning in Higher Education: Volume 3. Colorado: Educause

Bandura, A. 1977. Social Learning Theory. New York: General Learning Press

Bugman, Adi. 2012. Pengaruh pemanfaatan blog dan media sosial internet bagi guru terhadap prestasi belajar siswa kelas XI-IPA SMAN 4 Balikpapan. Tesis Tidak diterbitkan. Universitas Mulawarman

Ibrahim, R dan Ali Mohammad. 2007. Teori Andragogi. Dalam Ali, M.; Ibrahim, R.;Sukmadinata, N.S.;Rasyidin, W. (penyunting). Ilmu dan Aplikasi Pendidikan: Handbook (103 - 124). Bandung: Pedagogian Press

Knowless, Malcolm. 1970. The modern Practice of Adult Education: Andragogy versus Pedagogy. New York: Association Press

Lim, Doo Hun; Michael lane Morris. 2009. Learner and Instructional Faktors Influencing Learning Outcomes within a Blended learning Environment. Educational Technology \& Society Journal, 12 (4), 282-293. 
Noe, Raymond A. 1994. Human Resource Management: Gaining a Competitive Advantage. Canada: Mc. Graw-Hill Higher Education

Woolfolk, Anita. 2007. Education Psychology: Ninth Edition. Boston: Pearson 